\begin{tabular}{c}
\hline Review of \\
ECONOMICS \\
and \\
INSTITUTIONS
\end{tabular}

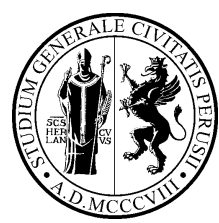

www.rei.unipg.it

\title{
Sudden Stops in the Euro Area
}

\author{
Silvia Merler* \\ Jean Pisani-Ferry \\ Bruegel \\ Bruegel, University \\ Paris-Dauphine
}

\begin{abstract}
The single currency was expected to make national balance of payments irrelevant for euro-area members. From 2010 onwards, however, governments, but also banks and non-financial companies in several euro-area countries have had difficulty getting access to non-resident financing.

Assessing whether there has been a balance-of-payment crisis by looking at the currentaccount developments is a flawed approach in the case of countries that receive significant official support through assistance programmes or the Eurosystem of central banks. In this paper we document the evolution of private capital flows and formally test for the existence of 'sudden stops'.

We find that Greece, Ireland, Italy, Portugal and Spain experienced significant privatecapital inflows from 2002 to 2007-09, followed by unambiguously massive outflows that qualify as 'sudden stops'. The timeline suggests contagion effects were present.

We document the substitution of the private capital flows by public flows. In particular, we show that (weak) banks in distressed countries took up a major share of central bank refinancing, thereby contributing to the build-up of intra-Eurosystem net balances.

The evidence that the euro area has been subject to internal balance-of-payment crises should be taken as a strong signal of weakness and as an invitation to systemic reform.
\end{abstract}

JEL classification: E58; F32; F34

Keywords: TARGET2, balance-of-payment crisis, capital flows, Euro area

(*) This paper was written and submitted when the author was working at Bruegel.

$\square$ Corresponding author. Bruegel, Rue de la Charité 33-1210 Brussels - Belgium. (Phone: +32 222742 10. Email: silvia.merler@bruegel.org).

\section{Recommended Citation}

Merler, S., \& Pisani-Ferry, J. (2012). Sudden Stops in the Euro Area. Review of Economics and Institutions, 3(3), Article 5. doi: 10.5202/rei.v3i3.97.

Retrieved from http://www.rei.unipg.it/rei/article/view/97 


\section{Introduction}

Since Greece filed for assistance in early 2010, there has been a debate on the nature of the crisis the euro area is confronted to. The official view has treated it as rooted in the fiscal crises of problem countries. But there has been another view, which claims that these countries have at least as much suffered from a balance-of-payments crises. This claim has a bearing on the nature of the policy response, which, until the adoption of a blueprint for banking union in June 2012, concentrated on strengthening budgetary discipline and treated external imbalances as a second-order matter.

The issue has become of major relevance with the accumulation by euroarea central banks of net balances vis-à-vis the ECB, as recorded within the framework of the TARGET2 settlement system - the Eurosystem's interbank payment system.$^{1}$ The cumulated net position of the northern euro-area central banks vis-à-vis the ECB reached 800 billion in December 2011 and surpassed 1 trillion in July 2012, being matched by the southern euro-area central banks' equivalent negative position.

A growing body of literature has recently been drawing attention on the role of external imbalances ${ }^{2}$ in the euro crisis and has highlighted the importance of intra-euro area capital flows.$^{3}$ The balance-of-payments discussion lacks clarity, however. First, it seems awkward to speak of balanceof-payments crises within a monetary union that was designed to make such crises impossible. Second, the balance-of-payments crisis view has not been substantiated by clear evidence. Unlike a standard balance-ofpayments crisis, within the euro area, current-account deficits have adjusted partially and slowly. Third, the relationship between TARGET2 balances and balance-of payment imbalances remains confused.

The purpose of this paper is to fill these gaps. We start in Section 2 with a brief discussion of the possibility of a balance-of-payment crisis within a monetary union and an overview of the evolution of current-account balances. In Section 3 we analyse the evolution of private capital flows to southern Europe before and during the euro crisis. In Section 4 we proceed to a more formal test and apply standard sudden-stop criteria to the evolution of capital flows. In Section 5 we discuss the roles played by central banks and official financing. We return to policy issues in Section 6 to discuss the consequences of our findings.

1 The Eurosystem is the monetary authority of the euro area, comprising the European Central Bank and the central banks of countries using the euro.

2 For example, Higgins and Klitgaard (2011)

3 See for example Waysand et al (2010), Giavazzi and Spaventa (2011), and more recently Alessandrini et al. (2012), Carney (2012), Lane and Pels (2012), Milesi-Ferretti et al. (2012), Obstfeld (2012), Sinn (2012); Martin Wolf in the Financial Times also has reflected this on a number of occasions. 


\section{Crisis? What Crisis?}

In one of the earliest papers on European monetary union, Ingram (1973) notes that in such a union "payments imbalances among member nations can be financed in the short run through the financial markets, without need for interventions by a monetary authority. Intra-community payments become analogous to interregional payments within a single country" 4

This view was not challenged in the debate of the 1980s and the 1990s on the economics of Economic and Monetary Union (EMU). It quickly became conventional wisdom. The European Commission's One Market, One Money report (1990) similarly posits that "a major effect of EMU is that balanceof-payments constraints will disappear [..]. Private markets will finance all viable borrowers, and savings and investment balances will no longer be constraints at the national level".5 The important words here are "all viable borrowers", meaning that the budget constraint applies to individual borrowers, not to countries as such. In other words a solvent company in Italy or a solvent bank in Spain cannot be cut off from market financing because of the situation of the sovereign or the households. There is no such thing as a specific country-level inter-temporal budget constraint - only those of individual agents matter.

This view was so widespread in the early 1990s that the Maastricht negotiators decided to exclude members of the common currency from the benefit of EU balance-of-payments assistance under Article 143 of the Treaty with the result that the euro area was left without an instrument to provide assistance to Greece and had to rely in a first step on bilateral loans from its member countries, before the European Financial Stability Facility and the European Stability Mechanism were created. As reported in Marzinotto et al. (2010), this exclusion had nothing to do with the no-bail out clause. It was simply assumed that balance-of-payment crises within the euro area would become as unthinkable as they are within countries ${ }^{6}$

To our knowledge, the only one to challenge this benign view was Peter Garber in a 1998 paper on the role of TARGET2 in a crisis of monetary union (Garber, 1998). The paper insightfully recognised that the federal structure of the Eurosystem and the corresponding continued existence of national central banks with separate individual balance sheets made it possible to imagine a speculative attack within monetary union. According to Garber, the precondition for an attack "must be scepticism that a strong currency national central bank will provide through TARGET] unlimited credit in euros to

\footnotetext{
${ }^{4}$ Ingram (1973), p. 10.

5 European Commission (1990), Synthesis chapter, p. 24.

6 The literature of the 1990s explored this comparison and showed that the FeldsteinHorioka paradox vanishes entirely when applied to regions within countries. See for example Bayoumi (1999).

7 "TARGET" was the predecessor of the TARGET2 System
} 
Figure 1 - A Tale of Two Adjustments: Current Accounts Outside and Within the Euro Area

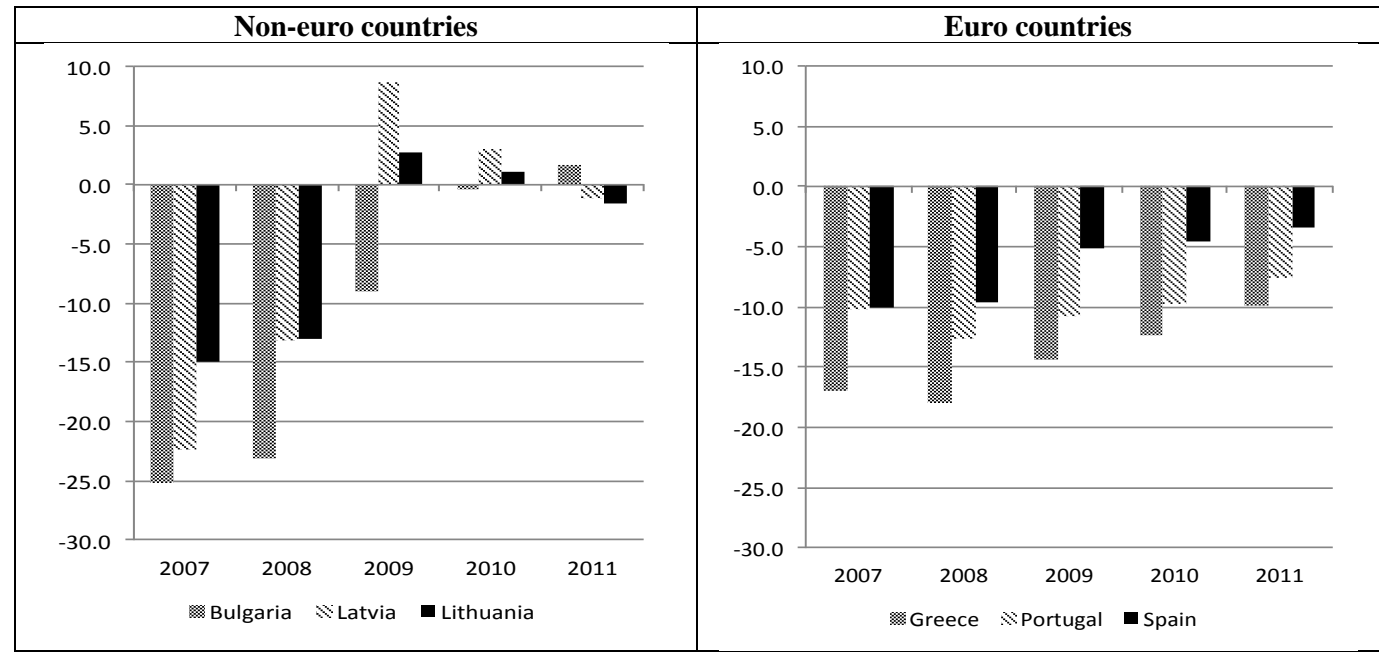

Source: ECFIN Forecasts May 2012

the weak national central banks". His conclusion is that "as long as some doubt remains about the permanence of Stage III exchange rates, the existence of the currently proposed structure of the ECB and TARGET does not create additional security against the possibility of an attack. Quite the contrary, it creates a perfect mechanism to make an explosive attack on the system".

As said, the benign view prevailed during the first ten years of EMU. It even continues to dominate today. Indeed, casual data observation seems to vindicate it. Figure 1 reports the 2007-11 evolution of current-account balances in the three non-euro area EU countries and the three euro-area countries with the highest deficits in 2007..$^{8}$ It is apparent that the two groups of countries have not followed the same path: whereas adjustment has been brutal for the first group, where deficits amounting to 15 to 25 percent of GDP have been transformed into surpluses in the course of three or four years, it has been very slow for the second. One may even wonder if Greece and Portugal have adjusted at all.

\section{Private Capital Flows}

Assessing if there has been a balance-of-payment crisis by looking at the evolution of the current account is however a flawed approach. It is adequate to look at the evolution of current-account balances as long as it offers a mirror image of net private capital flows. In a stand-alone country, this is largely the case except for foreign exchange interventions by the central bank - at least as long as the country is not under an International Monetary Fund programme. This is however not the case for monetary union, because

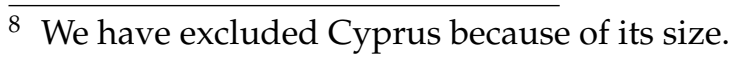


the financial account includes official capital flows. The correct accounting identity (neglecting the balance of the capital account as well as errors and omissions) is:

$$
C A B+P C I+T 2 F+P G M+S M P=0
$$

where $C A B$ stands for the current-account balance, PCI for private capital inflows, T2F for Eurosystem financing through the TARGET2 system (change in the net liability of the national central bank vis-à-vis the rest of the Eurosystem), PGM for financing through official IMF and European assistance, and SMP for flows arising from transactions operated within the Securities Markets Programme, the Eurosystem's government securities purchase scheme.

Of these five flows, four are recorded statistically and only one (SMP) is not known. Whether the SMP should be included into equation (1) is not straightforward, as it depends on which entity operatively bought the securities held by the Eurosystem, and from which agent. For example, if the central bank of Italy bought Italian government bonds from Italian banks, that would not affect in any way the balance of payment, as it would amount to a completely domestic transaction. On the other hand, if the Central bank of Italy were to buy Italian bonds that are off-loaded by German banks, then the transaction would be cross-boarder and therefore affect the balance of payments. In both cases, the financing of the same Italian liability (represented by the bonds) switches from private to public, but only in the second case we have an effect on the financial account. Unfortunately we cannot disentangle the different transactions conducted in the SMP framework and we therefore do not take it into account in our empirical assessment.

In what follows we evaluate private capital inflows to southern Europe from January 2002 onwards, using monthly financial account data. Capital flows are taken from national balance-of-payments as published by national central banks, and we deduct from them official inflows resulting from changes in TARGET2 balances (see Appendix 1) and assistance under IMF/EU programmes.

As we want to focus on inflows and reversals, not short-term fluctuations, and to compare evolutions across countries, we plot for all countries cumulated capital inflows in proportion to their 2007 GDPs, taking as a starting point the end-2001 net investment position of the country as recorded by Eurostat..$^{9}$ Figure 2 presents the results for Greece, Ireland, Italy, Portugal and Spain. In each case the black line gives total cumulated flows,

9 We cannot exactly replicate the evolution of the international investment position simply by cumulating financial account flows. This is because the international investment position can be subject to important valuation effect, among which the effect of market prices and of exchange rates (European Commission 2006). 
Figure 2 - Total and Private Capital Inflows, Selected Southern Euro-Area Countries, 2002-2012
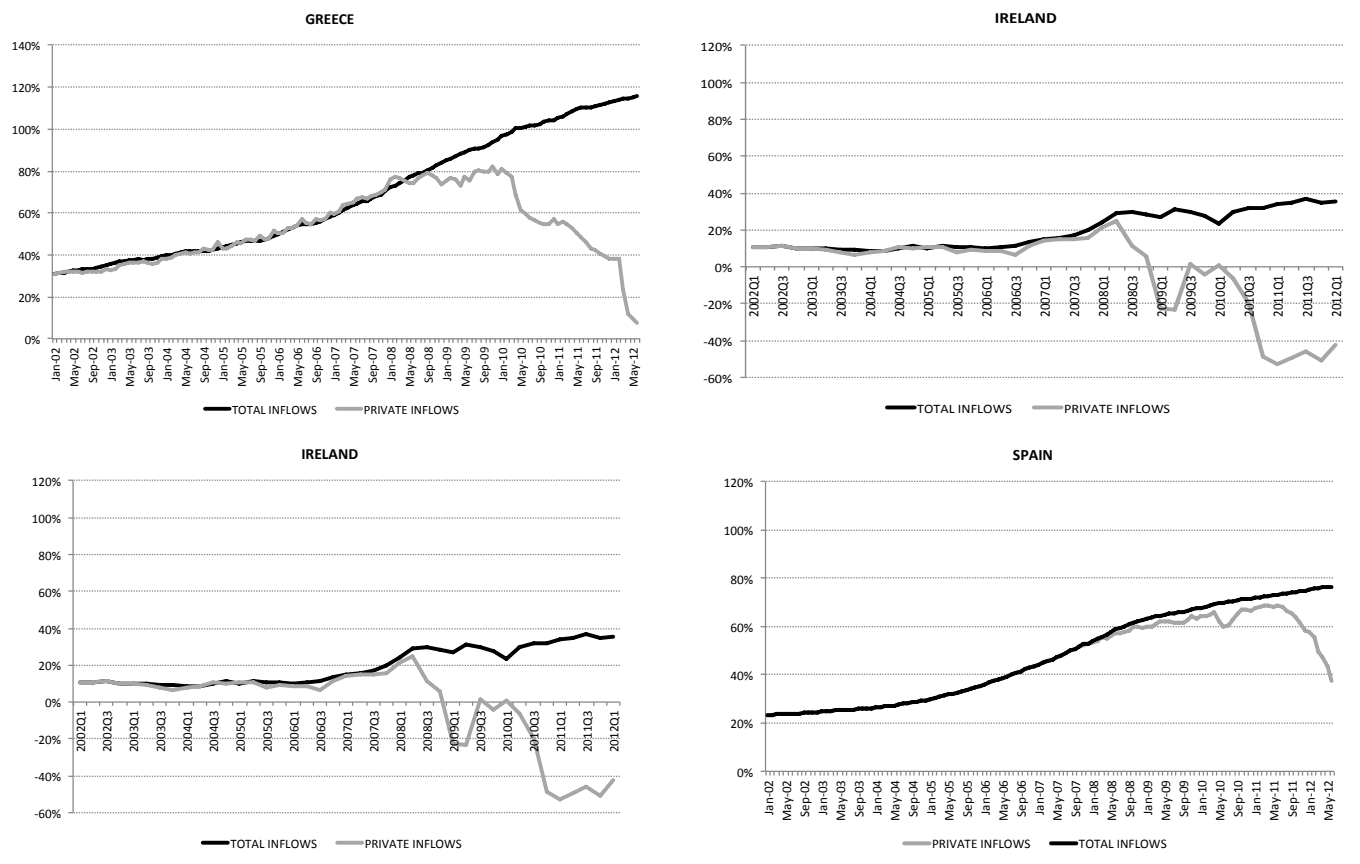

ITALY

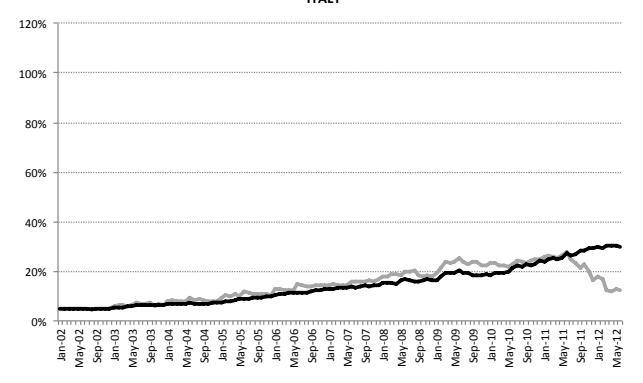

Source: Bruegel calculations with national and Eurostat data

and the grey line total cumulated private flows.

Figure 2 provides evidence that all five countries experienced significant private capital inflows from 2002 to 2007-09, followed by unambiguous and sudden outflows. In Greece, capital inflows had dropped by $40 \%$ of pre-crisis GDP as of December 2011 and by 70\% as of June 2012, after the enforcement of the Private Sector Involvement (PSI). In Ireland inflows were limited but outflows reached 70 percent of 2007 GDP. In the other three countries outflows were less sizeable and started later, but nevertheless they were of significant size.

It is interesting also to observe the timing of reversals: capital stopped flying into Greece even before the announcement in October 2009 by the Papandreou government that public finance data had misreported deficit and debt. In Portugal there was a noticeable outflow at the time of the first Greek programme in spring 2010, followed by a second outflow in early 2011. In Ireland, private capital inflows dropped the first time in the early stage of 


\section{Figure 3 - Identifying Sudden Stops: Greece}

\section{GREECE - Evidence of Sudden Stops}

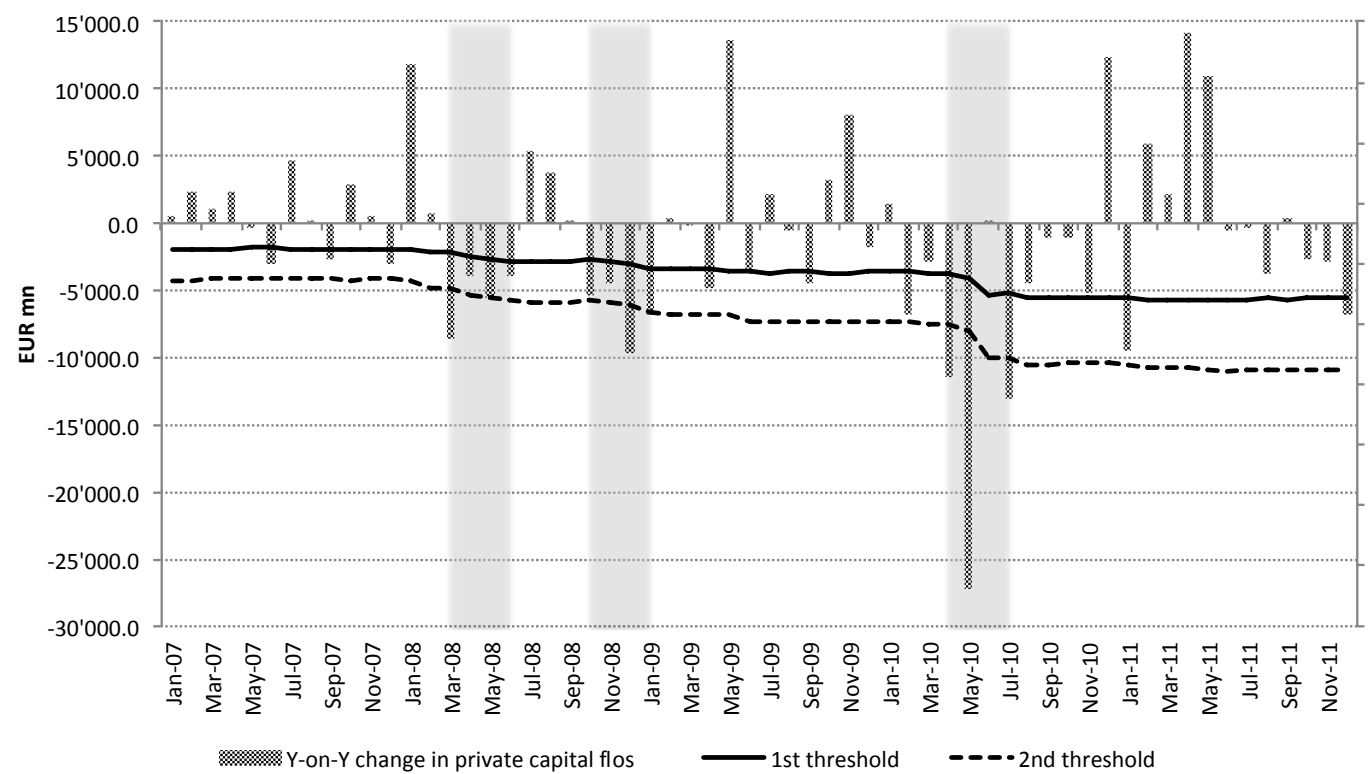

Note: Authors' calculations with data from national authorities.

$1^{\text {st }}$ Threshold is computed as the average of year-on-year change in capital flows minus one standard deviation; $2^{\text {nd }}$ Threshold is computed as the average of year-on-year change in capital flows minus two standard deviations.

the financial crisis (2008Q3). The outflow then paused temporarily, starting again when the Greek programme was agreed in the second quarter of 2010. In Spain also there was a first, short-lived outflow in spring 2010, followed by a second starting in summer 2011, concurrent with the one experience by Italy.

\section{Evidence of Sudden Stops}

Figure 2 provides prima facie evidence of sudden stops of capital inflows. In what follows we complement this observation with a more formal test based on the methodology introduced by Calvo (2004). The Calvo methodology is based on monthly data and identifies a sudden stop as an episode in which there is at least one observation with year-on-year capital inflows two standard deviations below the mean. This methodology has two advantages: first, it provides a more rigorous and systematic comparison of the experience within the euro area with the experience of emerging countries; second, it dates the sudden stop.

After a sudden stop has been identified, it is considered to start with the first observation for which changes in capital flows are one standard deviation below the mean, and to end with the first observation for which they return above one standard deviation below the mean (see Appendix 2 for details). In Figure 3, we present the application of this methodology to the case of Greece. The shaded areas correspond to sudden stop episodes. 
It is apparent in Figure 3 that the Calvo methodology provides a straightforward way to identify a sudden stop that takes place after a sustained period of capital inflows, but the methodology yields more ambiguous results when it comes to identifying sudden stops that take place during protracted periods of capital outflows. An alternative to the Calvo methodology is to freeze the thresholds after the first episode, instead of de facto toughening the criterion, as apparent in Figure 3. We use both methodologies, and find no significant difference in results except for Ireland, for which the fixedthreshold methodology results in the identification of a series of sudden stop episodes throughout 2010 (see Appendix 1).

The dating of sudden stop episodes helps identify contagion effects, showing how reversals of capital flows affected all crises countries one after the other. Figure 4 shows the number of countries in a sudden stop episode (counting only episodes of at least three months in order to eliminate shortterm variations). We find three periods of sudden stop episodes:

- The global financial crisis. The rise in risk aversion and the clogging of the interbank market affected both Greece and Ireland. Capital started flowing out of Greece early in 2008 (between March and June), before the Lehman shock and well before the misreporting of fiscal statistics was revealed. This phase was followed by another episode between October 2008 and January 2009, corresponding with the intensification of the financial crisis. At the same time, private capital also started leaving Ireland, which entered a long sudden stop phase (2008Q3 to 2009Q1).

- Spring 2010. The agreement of the IMF/EU programme marked the beginning of a third Greek episode (April 2010 to July 2010,10 ${ }^{10}$ which also triggered an impressive contagion effect. Portugal entered a sudden stop immediately but it was relatively short, whereas Ireland experienced a serious and prolonged capital outflow that eventually led the country to ask for support.

- End 2011. The third wave of sudden stops involved Italy ${ }^{11}$ and Spain - both put under increased scrutiny and pressure by sovereign bond markets during the summer - as well as Portugal.12 In early 2012,

${ }^{10}$ June 2010 would not satisfy formally the requirement of being at least one standard deviation below average. However, given that the year-on-year change in capital inflow is almost zero in June 2010 and it is preceded and followed by two observations falling below the second threshold, we decided to include it in the sudden stop period.

${ }^{11}$ As in the case of Greece, the observation of October 2011 would not satisfy the criterion, but the y-on-y positive change is very small and followed by two observations below the second threshold, so we include it in the sudden stop.

${ }^{12}$ Contrary to reasonable expectations, we cannot detect (at least using Calvo's methodology) any episode of sudden stop for Portugal in May 2011, even though the cumulative capital flows continued to fall steadily. In this respect, it is important to recall that we are 
Figure 4 - Sudden Stop Episodes in Southern Euro-Area Countries, 2009-2011 Episodes of Sudden Stops

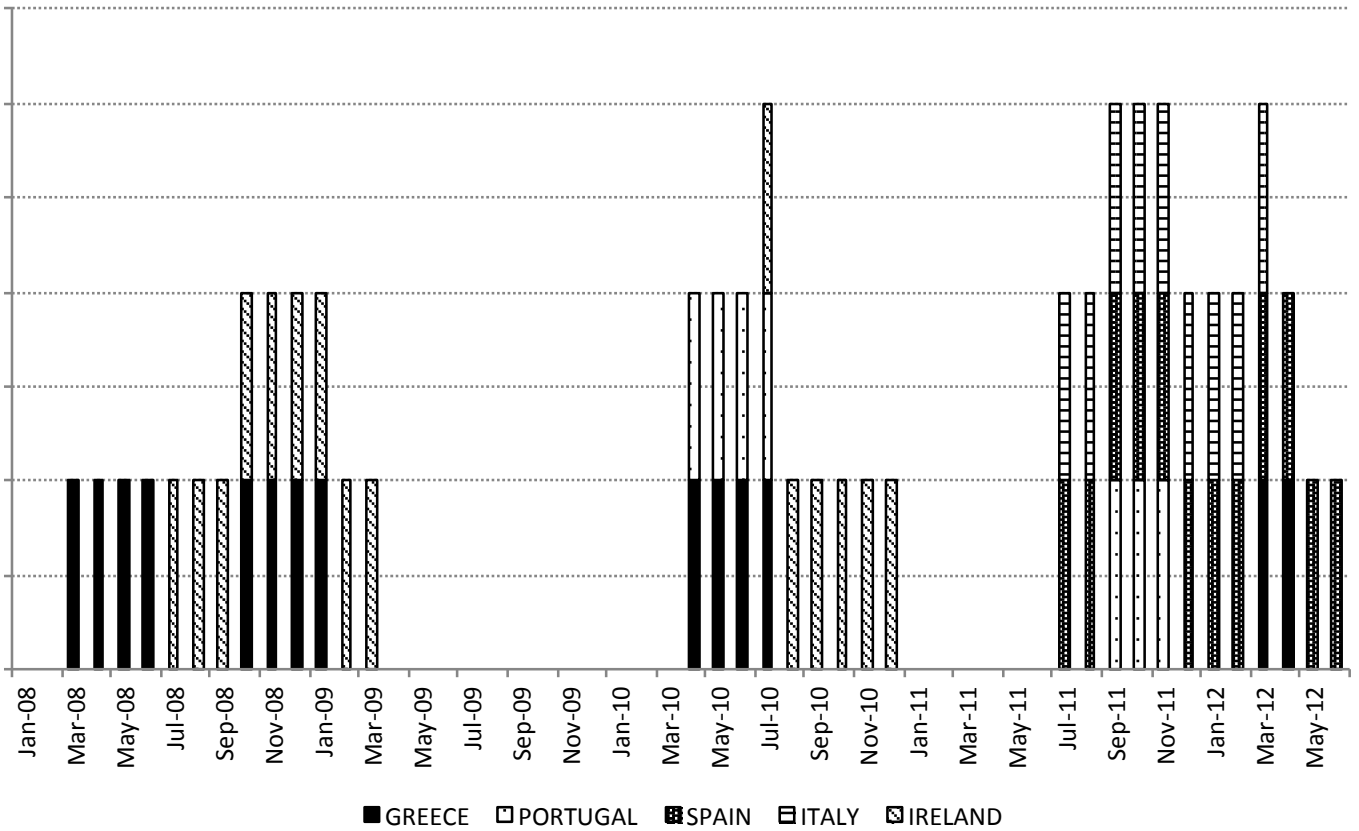

Greece also experienced another episode of sudden stop, probably in connection with debt restructuring and anticipations of euro exit.

An important question is if capital outflows simply result from sovereign crises, i.e. from the disposal by non-residents of their portfolios of government securities, or if their impact is broader, also affecting solvent private agents. ${ }^{13}$ It is only in the second case that it is justified to challenge conventional wisdom and speak of balance-of-payment crises instead of sovereign crises. Lack of detailed comparable data does not make it possible to proceed to a formal test, but discussion can draw on orders of magnitude in the cases of Italy and Spain.

In the Italian case, data on holdings of government debt by agents measured at nominal value are available and can be compared to balance-ofpayment flows. Outflows during the end-2011 episode were significantly larger than the selling of government bonds by non-residents, which suggests that other agents were also affected by the sudden stop. For Spain, the same can be done but with quarterly data only. Again, the data indicates that the outflows meaningfully exceeded what could be accounted for by the withdrawal of non-residents from the government bond market. These are rough assessments, and our estimate of capital outflows is admittedly

not taking the Securities Markets Programme (SMP) out of the financial account and this could partly account for the overestimation of capital inflows.

${ }^{13}$ See Merler and Pisani-Ferry (2012) for evidence on the withdrawal of non-residents from the government bonds market. 
imperfect because we do not take into account the impact of the SMP. But our reading of the evidence is that the data tends to confirm the view that capital outflows exceeded what can be explained by the withdrawal of nonresidents from the government bond market.

\section{The Role of Official Financing and the TAR- GET2 Debate}

The evidence presented in Section 4 shows that the three programme countries - and more recently Italy and Spain - have experienced significant reversals of capital inflows. This was not evident from the official balanceof-payment statistics, because the private capital outflows were compensated for by an equally sizeable increase in public capital inflows. These flows have prevented the official financial account from shrinking.

Public support has taken three forms in the euro area: EU/IMF assistance programmes; provision by the Eurosystem of liquidity to the banking sector (captured by the development of TARGET2 balances); and ECB purchases of sovereign bonds under the SMP. As previously discussed, we have not been able to build estimates for the third component, so our estimates of private capital inflows tend to err on the optimistic side.

Figure 5 shows the relative size and importance of the two first components in filling the void left by private capital flight. The decomposition is obtained simply by cumulating separately changes in TARGET2 net liabilities, programme flows, and our measure of private capital inflows over the same period (2002-11) for all countries. The sum of these three components has been plotted against the cumulated total inflow (the official financial account data).

For Greece, at the end of 2011, programme and TARGET2 liabilities accounted respectively for 44 percent and 56 percent of total official financing. For other countries, however, TARGET2 financing was by far the largest component. At the end of 2011, intra-Eurosystem liabilities amounted to 68 percent of GDP in Ireland and 32 percent in Portugal, against only 14 percent and 19 percent respectively accounted for by the programme in the two countries. Eurosystem financing has also been sizable in Italy and Spain, amounting to 13 percent and 17 percent of GDP respectively, as of December 2011. With the exception of Ireland, the worsened everywhere in the first half of 2012 but much more so in Italy and Spain, where TARGET2 financing amounted to 18 percent and 39 percent of 2007 GDP in July 2012.

These findings help to shed light on the debate on the role of TARGET2 financing. Early contributions focused mostly on the link between these balances and current-account balances, arguing that the former financed the latter to some extent. As we have shown, the pace of current-account adjustment in the euro area was clearly much slower than for non-euro 
Figure 5 - Decomposition of Cumulative Capital Flows (\% of 2007 GDP)
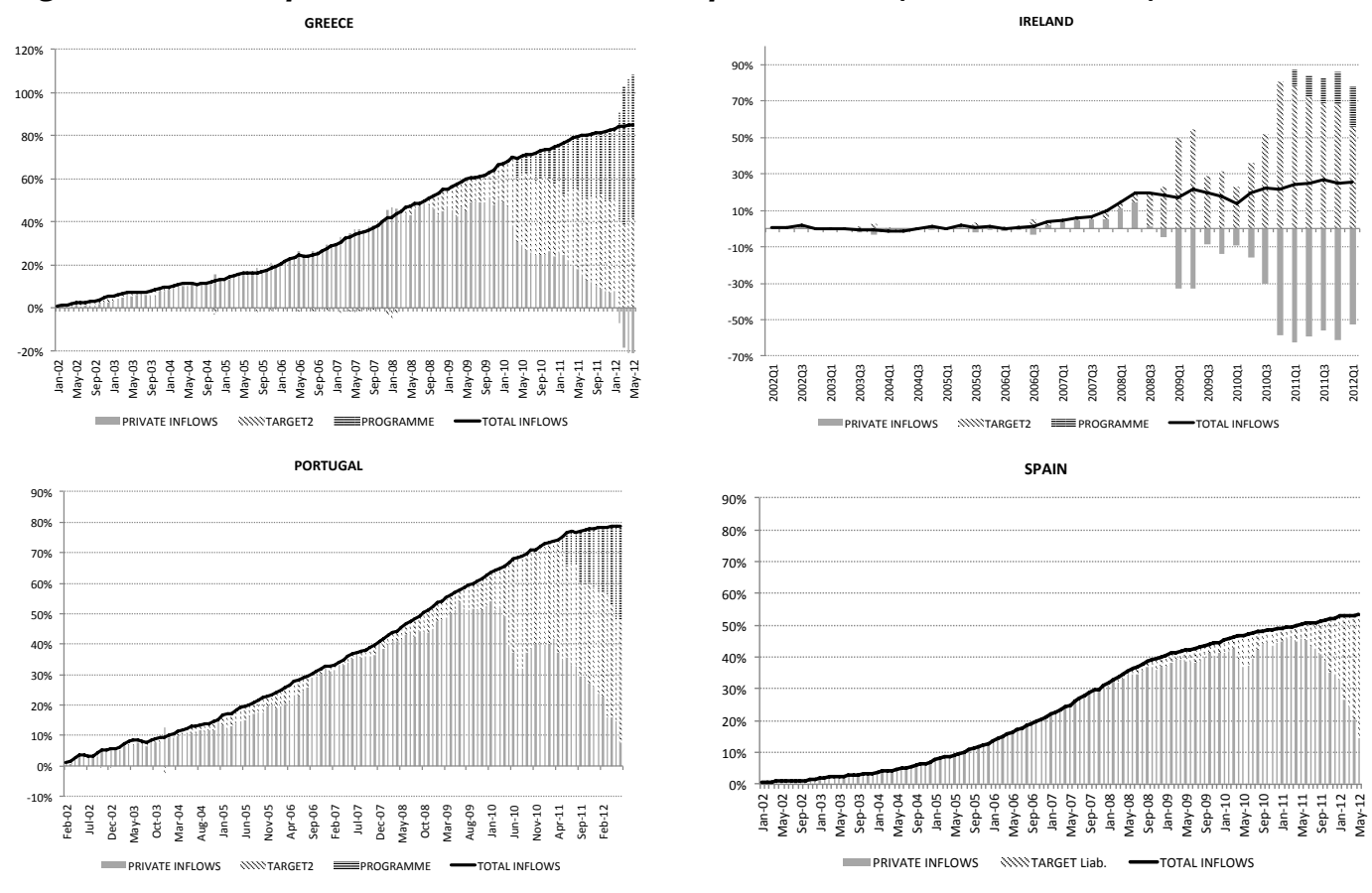

ITALY

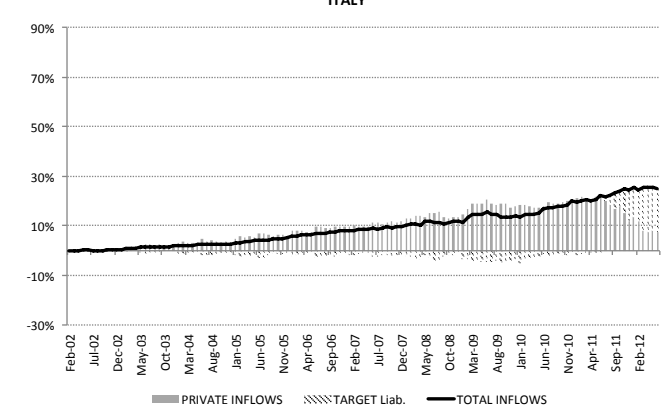

Source: Bruegel based on national central banks, ECFIN, IMF, EFSF 
area EU countries. Substitution of private-capital inflows by public inflows, especially Eurosystem financing, helped accommodate persistent currentaccount deficits in a context in which capital markets were no longer willing to accommodate them.

However, large current-account balances per se are neither a necessary nor a sufficient condition for incurring significant TARGET2 liabilities (Bindseil and Winckler, 2012). What was instead crucial was how these currentaccount balances were financed in the euro area before the outbreak of the financial crisis. As stressed by the European Commission already in 2006 (European Commission, 2006), the countries with large current-account deficits (Greece, Portugal and Spain) were mostly financed via portfolio debt securities and bank loans, whereas the contribution of foreign direct investment was very limited. Such a financing structure, biased towards banks' intermediation, rendered the deficit countries very exposed to the unwinding of capital inflows, especially in a financial crisis. We have shown that a reversal of private inflows indeed took place and that it was sizeable enough to qualify as a sudden stop. The Eurosystem has provided a buffer against the associated drying up of liquidity on the interbank market, and this is reflected in the evolution of intra-Eurosystem claims.

Reliance on Eurosystem financing primarily reflects the distress of euroarea banking systems in the aftermath of the global crisis. The difficulty that banks had to refinance on the interbank market led the Eurosystem to perform this standard role as a lender of last resort to the banking system through the provision of liquidity in large amounts. From October 2008 onwards, the fixed-rate, full allotment procedure adopted by the ECB made a large part of the euro-area banking system reliant on central bank financing, while weak banks in distressed countries ended up taking up a disproportionately large part of the central bank refinancing (Figure 6). These figures do not include the Emergency Liquidity Assistance (ELA) extended by single national central banks to their banking systems. ELA - the risk being entirely borne at national level - has been extensively used in Ireland and more recently also in Greece, where the government has approved 60 billion in guarantees to facilitate the process (IMF, 2011). Before a reclassification took place in April 2012, the operation was generally recorded in central banks' balance sheets under 'Other assets' (Figure 6), an item that amounted to 41 billion in Ireland and 51 billion in Greece as of July 2012.14 In Greece, the provision of ELA jumped to about 100 billion in February,

\footnotetext{
${ }^{14}$ There is lack of transparency in both the financing and the amount of ELA, but there is consensus on the fact that the operation is recorded under 'Other assets' (see, for example, Buiter, 2010). This is reinforced by the jump observable in this item in crisis periods. For Greece in particular 'Other items' reached 58 billion in November 2011, very close to the 60 billion in guarantees the Greek government approved to back ELA (IMF, 2011). Recently, the ELA has been reclassified under the item "other claims on euro area credit institutions in euro". The series showed in the graphs is therefore constructed as a combination of the two.
} 
Figure 6 - Share of Countries Affected by Sudden Stops in Take-Up of Eurosystem Liquidity and ELA

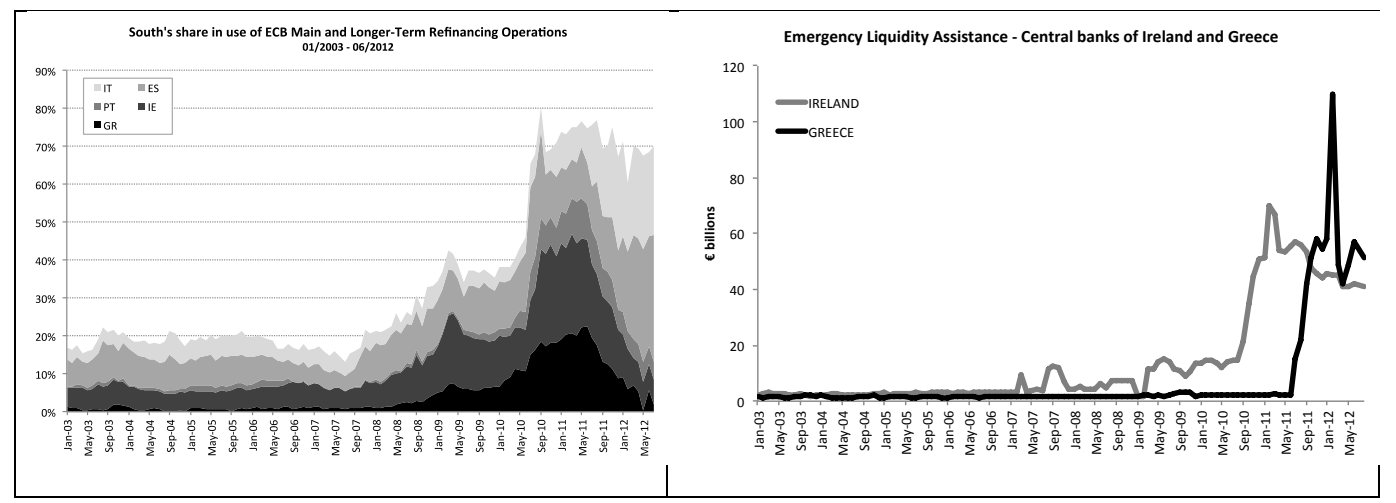

Source: national central banks.

in correspondence with the PSI. The rationale for ELA is to ensure that the banking system can access liquidity even when it faces shortages of good collateral to pledge at the ECB. Therefore, any tightening of collateral requirements that makes it more difficult for banks to access ECB refinancing could result in a larger share of the demand for central bank liquidity being covered by national emergency liquidity assistance.

These developments raise an analytical question and a policy question. The analytical question is whether the low cost of ECB refinancing and its long maturity (especially but not only since the launch of the threeyear Long-Term Refinancing Operations (LTRO) in December 2011) contributed to the increase in demand for Eurosystem financing, crowding out private capital flows. The correlation between private capital outflows and increased reliance on Eurosystem financing should be treated with care, because causality could run in both directions. However, for each of our three periods of capital outflows we find hard to reconcile the view that private capital could be been crowded out with the sequence of events. The first period started before the adoption by the ECB of its fixed rate, full allotment procedure. In the second period, the coincidence of the drops in private capital flows experienced by Greece, Ireland and Portugal suggests that it was the change in market sentiment rather than the availability of ECB financing that triggered the rise in intra-Eurosystem liabilities. Similarly, capital outflows from Italy and Spain in the second half of 2011 took place before, not after, the extension of the LTRO to three years.

Turning to policy, several proposals have been advanced to shelter national central banks from the perceived risk involved in the accumulation of positive TARGET2 balances. This risk however must be qualified:

- First, as far as TARGET2 balances reflect the uneven distribution of central bank liquidity within the Eurosystem, they do not entail specific risks for the creditor central banks, over and above the risk from monetary policy operations. Losses from Eurosystem monetary pol- 
icy operations could occur in case that there is counterparty failure and the value of collateral posted at the ECB is not sufficient to cover the claim entirely. Such losses would however be shared by national central banks according to the extent of their participation in the Eurosystem's capital. In other words, the possible loss faced by each national central bank would be the same, irrespective of the size of the TARGET2 claims/liabilities recorded in their own balance sheets. For example the Bundesbank, being the largest shareholder in ECB capital, would bear the greatest loss even if private capital flows from the periphery had been directed massively towards France rather than towards Germany.

- Second, the only scenario in which TARGET2 would represent an actual additional risk for national central banks would be if one (or more) country decided to leave the euro area and possibly default on its TARGET2 liabilities. In that case, the net claims against the rest of the system would constitute an additional risk. Any approach that would be interpreted as the introduction of a hedge against the break-up of the euro would involve the risk of sending the message that this break-up is indeed likely.

- Third, any proposal to limit the size of TARGET2 balances to a fixed threshold underestimates both the importance of a smoothly functioning payment system in a currency union, and the risk of speculative attacks that such limits would imply. The purpose of introducing the single currency was to overcome the weaknesses of fixed-exchange regimes, and this requires all capital flows between members to be treated in the same way. Placing caps on the size of TARGET2 balances would imply that euros would be entirely fungible across countries only up to a limit (Bindseil and Koenig, 2012), and this would in turn implicitly amount to the creation of two currencies. The threshold would offer a clear target to speculators in the same way that limited reserves offer a target in a fixed exchange-rate regime. Other proposals include the 'collateralising' of the TARGET2 balances of weaker countries and their disposal for an annual settlement (Sinn and Wollmerhaeuser, 2012). Though more reasonable in principle, an approach of this sort would give an incentive for speculation against the possibility of the exhaustion of collateral reserves or the inability/unwillingness of countries to mobilise resources for periodic settlements.

TARGET2 balances are the symptom of the uneven distribution of central bank liquidity within the Eurosystem. To focus on TARGET2 imbalances as having significance is to confuse consequence and causes. Rather than tinkering with the symptom, with the risk of creating doubts about the very viability of the euro, attention should focus on curing the disease, in other words the underlying banking-system problems. 
The introduction of a three-year LTRO at the end of 2011, and the extension of the range of eligible collateral, resulted from the Eurosystem's assessment that the risk of a funding crisis in major countries was significant enough for a massive provision of liquidity to be necessary, even though it implied almost by definition a widening of the TARGET 2 imbalances. Only if the situation normalises further will the Eurosystem be able to mop up liquidity, reinstate its collateral policy and thereby contribute to the gradual unwinding of these imbalances.

More fundamentally, a structural response to the problem requires that the causes of financial fragmentation be addressed. Adjustment programmes and the move to a European banking union where states are not the exclusive backstop of banks in their jurisdiction anymore are intended to contribute to this repair.

\section{Conclusions}

European monetary union involved from the outset many 'known unknowns' and a few 'unknown unknowns'. The possibility that countries within the monetary union would experience balance-of-payment crises belonged to the latter category: conventional wisdom in research and policy was that among euro-area countries, balance-of-payments would become as irrelevant as among regions within a country. Yet developments since 2009 have challenged the wisdom of this view.

In this paper we have examined in detail the financial account of five southern European countries, and have provided evidence of a dramatic reversal in their private components. Considering only the private capital flows, we find that all countries have undergone episodes of sudden stops, more usually seen in emerging markets. These episodes were clustered in three phases (the outbreak of the global financial crisis; spring 2010 at the time of the launch of the Greek programme; and the second half of 2011), which suggests that there has been contagion across countries.

Countries within the euro area can experience such crises because they do not exhibit the same degree of market and policy integration as regions within a country. Regions rarely rely on their own banking systems, implying that the bursting of a regional credit bubble will not translate into a banking crisis. Should a banking crisis nevertheless develop, it does not affect the regional state because responsibility for bank rescue and restructuring is generally a federal competence. Regions therefore can hardly be subject to confidence crises of the sort that affected euro-area countries.

A striking feature of the euro-area crisis is that whereas capital outflows have been dramatic, the current accounts of deficit countries have adjusted only partially. Decomposition of capital inflows highlights the crucial role of Eurosystem financing in mitigating the effect of private capital outflows (with a contribution of international financial assistance of a comparable or- 
der of magnitude in the case of Greece). The injection of liquidity has helped accommodate persistent current-account adjustments in the southern part of the euro area, but most importantly it has protected countries that could no longer rely on adjusting their exchange rates from the full negative impact of a sudden stop. Given the level of integration of euro-area financial markets, the effects of unmitigated sudden stops in southern Europe would have endangered the entire system and put at risk the survival of the single currency.

The smooth functioning of a payment system is essential for maintaining the stability of the financial system, preserving confidence in the common currency and allowing the implementation of a single monetary policy. Introducing constraints on the operations of the payment system would suggest an unwillingness to provide unlimited liquidity across the euro area and open a window for speculation. The more important question is how to address the underlying disease. The cure is likely to require interventions to foster the sustainability of public finances, the resilience of the financial system, and the creation of a banking union as officially contemplated since June 2012. However confidence cannot be regained overnight and in the meantime, the Eurosystem should not be blamed for playing fully its role.

For the longer run, the evidence that the euro area went through internal balance-of-payment crises should be taken as a clear signal of weakness and as an invitation to reform its structures. Contrary to common belief, a monetary union of this sort is closer to a fixed exchange-rate system among independent countries than to a fully integrated economy. Financial-market participants have realised this and certainly will not forget it. Only closer policy integration will preserve the euro area from the risk of further attacks. 


\section{References}

Alessandrini, P., Fratianni, M., Hughes Hallet, A., Presbitero, A.F., 2012. External imbalances and financial fragility in the euro area. MoFiR Working Paper 66.

Bayoumi, T., 1999. Is There a World Capital Market?. In: Siebert, H. (Ed.), Globalisation and Labour. Tuebingen: J.C.B. Mohr.

Bindseil, U., König, P.J., 2011. The Economics of TARGET2 Balances. SFB 649 Discussion Paper 2011-035.

Bindseil, U., König, P.J., 2012. TARGET2 and the European Sovereign Debt Crisis. Mimeo February.

Bindseil, U. Winckler, A., 2012. Dual Liquidity Crises Under Alternative Monetary Frameworks - a Financial Accounts Perspective. Mimeo, February.

Buiter, W., Michels, J., Rahbari, E., 2011. ELA: an Emperor without Clothes?. CITI Global Economics, January.

BIS 2003. Payment System in the Euro Area.

Bornhorst, F., Mody, A., 2012. TARGET Imbalances: Financing the CapitalAccount Reversal in Europe. Vox-EU, 7 March.

Buiter, W.H., Rahbari, E., Michels, J., 2011. The Implications of IntraEurozone Imbalances in Credit Flows. CEPR Policy Insight No. 57.

Calvo, G.A., Izquierdo, A., Mejia, L.F., 2004. On the Empirics of Sudden Stops: the Relevance of Balance Sheet Effects. NBER Working Paper 10520.

Carney, M., 2012. Remarks at the World Economic Forum, 28 January.

Chen, R., Milesi-Ferretti, G. M., Tressel, T., 2012. External Imbalances in the Euro Area. IMF Working Paper 12/236.

Deutsche Bundesbank, 2011. Monthly Report . The German Balance of Payments. March 2011.

European Central Bank, 2011. Monthly Bulletin. October.

European Commission, 1990. One Market, One Money: an Evaluation if the Potential Benefits and Costs of Forming a Monetary Union. European Economy No44.

European Commission, 2006. Quarterly Report on the Euro Area. 
Eichengreen B., Gupta, P., Mody, A., 2006. Sudden Stops and IMFSupported Programmes. IMF WP/06/101.

Garber, P.M., 1998. Notes on the Role of Target in a Stage III Crisis. NBER Working Paper 6619.

Garber, P.M., 2010. The Mechanics of Intra Euro Capital Flight. Deutsche Bank Research Special Report.

Giavazzi, F., Spaventa, L., 2010. Why the Current Account May Matter in a Monetary Union: Lessons from the Financial Crisis in the Euro Area. CEPR Discussion Paper 8008.

IMF, 2011. Greece: Fifth Review under the Stand-by Arrangement.

Ingram, J.C., 1973. The Case for European Monetary Integration. Essays in International Finance 98. Princeton: International Finance Section, Princeton University.

Kokkola, T., 2010. The Payment System. ECB.

Lane, P.R., Pels, B., 2012. Current Account Imbalances in Europe. Moneda y Credito 234.

Marzinotto, B., Pisani-Ferry, J., Sapir, A., 2010. Two Crises, Two Responses. Bruegel Policy Brief 2010/1.

Merler, S., Pisani-Ferry, J., 2012. Who is Afraid of Sovereign Bonds? Bruegel Policy Contribution 2012/02.

Obstefld, M., 2012. Does the Current Account Still Matter? American Economic Review 102, 1-23. doi:10.1257/aer.102.3.1

Sinn, H-W., Wollmershaeuser, T., 2011. Target Loans, Current Account Balances and Capital Flows: The ECB's Rescue Facility. NBER Working Paper No. 17626.

Sinn, H.W., (Ed.), 2012. The European Balance of Payment Crisis. CESifo Forum Volume 13.

Weysand, C., Ross, K., de Guzman, J., 2010. European Financial Linkages: a new look at imbalances. IMF Working Paper 10/295.

Whittaker, J., 2011. Intra-Eurosystem Debts. Lancaster University Management School Monetary Research. 


\section{Appendix 1 - TARGET2}

TARGET2 (Trans-European Automated Real-time Gross settlement Express Transfer) is the Eurosystem's operational tool through which national central banks provide payment and settlement services for intra-euro area transactions. Intra-Eurosystem claims arise from different types of transactions and they can or cannot have a 'real' counterpart: they might be the result of transfers of goods that require a cross-border payment (i.e. imports) or the transfer of deposits to a different euro-area country. When capital is transferred (e.g. a deposit is moved) from an Irish bank to a German bank via TARGET2, the transaction is settled between the Irish central bank and the Bundesbank, with the former incurring a liability to the latter. TARGET2 can be used for all credit transfers in euro and it processes both interbank and customer payments. There are transactions for which TARGET2 must be used ${ }^{15}$ but for all the other payments - interbank and commercial payments in euro - market participants are free to use TARGET2 or any other payment system of their choice. Banks prefer the TARGET2 system because most banks in Europe are reachable through it and payments are settled immediately (immediate finality of the transaction) and in central bank money (allowing credit institutions to transfer money held in accounts with the central bank among themselves) ${ }^{16}$

The settlement of intra-Eurosystem payments via TARGET2 gives rise to cross-border obligations that are aggregated and netted out at the end of each single business day, leaving national central banks with a certain net TARGET2 balance. There is no a priori limit to the transactions that can be processed by the system - and therefore to the size of TARGET2 positions. Daily net balances are generally remunerated at the respective interest rate for main refinancing operations ${ }^{17}$

TARGET2 balances are balances that each central bank accumulates from the operations conducted vis-à-vis other national central banks in the euro area, but the aggregate balance is treated as a claim or a liability against the $\mathrm{ECB}$, the ultimate manager of liquidity. In a way, it is as if the ECB were intermediating all transactions among national central banks 18

Until 2007, TARGET2 positions remained close to balance. From 2007 (and more so with the intensifying of the sovereign debt crisis in 2010) the balances started to diverge, with Germany becoming the largest creditor, Greece, Spain, Ireland and Portugal being net borrowers, and Italy moving

\footnotetext{
${ }^{15}$ Operations including the Eurosystem monetary policy operations as well as for the settlement of position in large-value net settlement system that effectively operate in euro.

${ }^{16}$ See Kokkola (2010).

${ }^{17}$ Deutsche Bundesbank Annual Report 2010.

${ }^{18}$ The multilateralisation of the claims is an important feature of the system. It implies that any loss resulting from a central bank's failure to settle its debts would be shared among all the members of the Eurosystem, irrespective of their creditor or debtor positions in the TARGET2 system.
} 
Figure A1 - TARGET2 Balances in the Euro Area
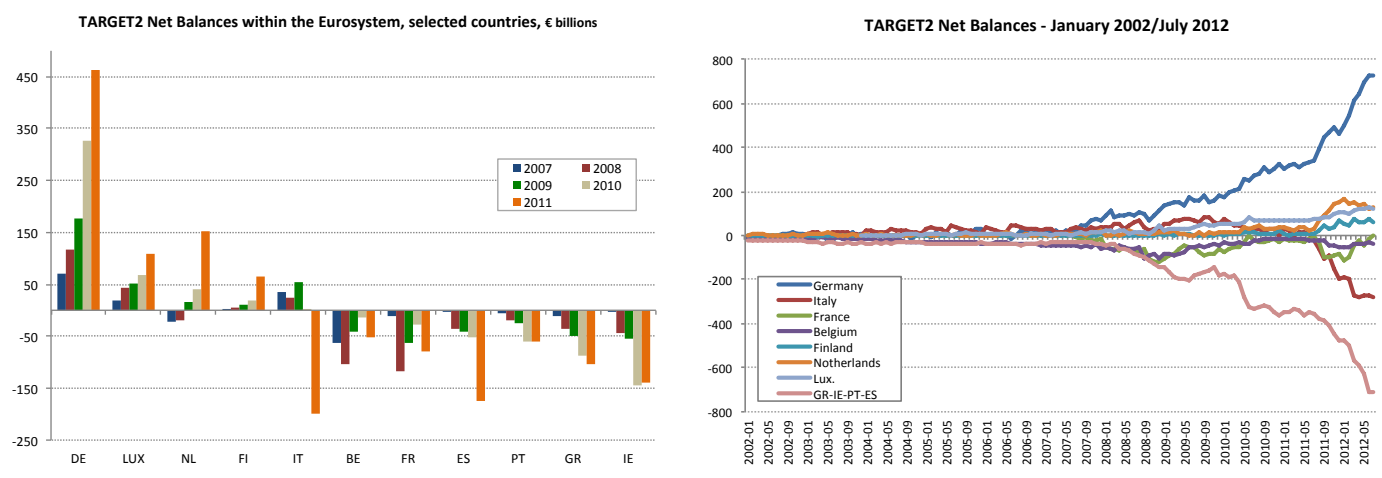

Source: Bruegel, National Central Banks

into a negative position during summer 2011. The huge increase in TARGET2 claims and liabilities became a topic for discussion in 2011, triggering a debate on the forces behind this steady divergence (see Sinn and Wollmerhaeuser, 2011; Buiter, Rahbari and Michels, 2011; Bindseil and Koenig, 2012; and Bornhorst and Mody, 2012).

The build-up of such imbalances indicates that central banks reporting a deficit position have been systematically settling more outward payments than inward payments. In other words, some countries have been constantly net borrowers and other countries have been net lenders. This development is closely related to the tensions on the interbank markets and the increase in the perceived country risk in southern Europe.

While payments between credit institutions can or cannot be processed via TARGET2, the transfers related to the Eurosystem monetary policy operations are managed through the system, so when the use of central bank liquidity becomes unevenly distributed across countries, TARGET2 balances will reflect it. The steep increase in corresponding claims and liabilities from 2008 onwards suggests that tensions in the financial system may have an important role in explaining the divergence. In a period of financial crisis, banks in countries undergoing net payment outflows find it difficult to refinance on the interbank market and will therefore resort more to central bank liquidity than banks in countries to which money is flowing.

The volume of central bank refinancing attributable to German banks decreased from 250 billion at the start of 2007 to 130 billion in 2010, ${ }^{19}$ signalling that German banks have reduced their reliance on central bank liquidity. Symmetrically, demand for ECB liquidity from banks located in troubled countries increased considerably over the same period. TARGET2 imbalances can largely be interpreted as evidence of a changing distribution in countries' refinancing operations, and as a compensation mechanism that allows sound banks in stressed countries to cover their liquidity needs.

${ }^{19}$ Deutsche Bundesbank Monthly Report March 2011. 


\section{Appendix 2 - METHODOLOGY}

\section{Data}

Following Eichengreen et al. (2006) we focus on the financial account balance, a comprehensive variable that includes Net Foreign Direct Investments, Net Portfolio Investment and Net Other Investment ${ }^{20}$ To maximise the chances of detecting an episode of sudden stop we work with monthly data from National Central Banks or Statistical Offices. Only for Ireland we have to use quarterly data and adjust the computations accordingly. ${ }^{21}$

From the financial account we derive a measure of private capital flows, constructed as the official financial account net of the changes in TARGET2 balances and of the inflow associated to disbursements under the IMF/EU Programmes. Both these components are classified in balance-of-payment statistics under "Other Investment" (respectively of Monetary Authorities and of General Government) where they can be clearly identified, provided that the balance of payments is sufficiently disaggregated. Data on TARGET2 balances are not available for all countries over the same time span, ${ }^{22}$ but we include them since the earliest date we have.

\section{Identification of Sudden Stops}

With this measure of private capital flows, we assess whether a country has experienced a "Sudden Stop", i.e. a large and unexpected fall in capital inflows measured year-on-year to avoid seasonal fluctuations induced by monthly frequency. Following the methodology proposed by Calvo (2004) we identified a sudden stop as an episode with the following characteristics:

- At least one month in which capital flows fall (year-on-year) two standard deviation below the sample mean

- The start of a Sudden Stop coincides with the first months in which year-on-year change in capital flows drops one standard deviation below the mean (obviously a fall by two standard deviations below the

${ }^{20}$ Calvo (2004) deals with a panel of many countries (including also emerging ones), which makes it difficult to have conistent financial account data at monthly frequency. Therefore he uses a proxy constructed as the Trade balance net of change in foreign reserves. We do not have such problem because balance of payment data for Euro Area countries are generally published by Central Banks at monthly frequency.

${ }^{21}$ In particular: when dealing with monthly data all the computations are done on a minimum of 24 months of observations, whereas the equivalent with quarterly data is a minimum period of 8 quarters.

${ }^{22}$ For Portugal and Greece we have data since 2002; for Ireland since 2003; for Italy we would have data since 2004 but due to some inconsistencies between yearly and monthly data before 2004, we consider TARGET balances only starting from this date; for Spain we only have data since 2007. 
mean would also qualify as the trigger of a sudden stop, provided that it is not an extemporaneous one).

- The end of a Sudden Stop coincides with change in capital flows reverting to the mean, namely above average minus one standard deviation.

Again following Calvo (2004), both average and standard deviations are computed in each month over an expanding window with starting date fixed at the earliest data available and a minimum width of 24 months. Moments and threshold are computed in each month $t$ considering only data up to $(t-1)$, so excluding the potential crisis year. In this way we obtain "adaptive" thresholds that keep track of the past evolution of capital flows but at the same time incorporate the increase in the volatility of capital flows recorded towards the end of the time series and toughen the requirements accordingly. However, thresholds take some time to adapt and therefore we risk detecting too many episodes of sudden stops especially in periods of high volatility (e.g. during the financial crisis). Therefore we decide to complement Calvo's criteria with an additional requirement and consider only episode of sudden stops that lasts for at least 3 months. The time series of financial account have a different length for all countries, but for the purpose of identifying sudden stop we restricted the sample to the same period for all (2002-2011). We did this for the sake of consistency, but we also replicated the analysis considering the whole (different) periods and results are unaffected.

The Calvo methodology results in toughening the criterion for sudden stops in the case of repeated episodes. For this reason we have explored an alternative methodology to identify the months of sudden stop.

We "freeze" the thresholds at the value observed the last month before a significant capital drop ${ }^{23}$ and compared post-sudden stop observations with the pre-sudden stop threshold. This variation does not change anything relevant for Greece, Ireland, Portugal and Spain ${ }^{24}$ whereas it makes a difference for Ireland, stretching the second Irish episode over two more quarters. This is probably due to the fact that quarterly data miss most of the information given by monthly data and they are more sensitive to changes in the threshold.

${ }^{23}$ We identified the huge capital drop looking at the evolution of monthly financial account flows compared to their long-term average (the same drops are also evident in the cumulative capital inflows graphs).

${ }^{24}$ Only the third episode for Greece lasts 1 months longer, until September 2011. 
Figure A2 - Alternative Dating of Sudden Stops in the Case of Ireland IRELAND - Episodes of Sudden Stops

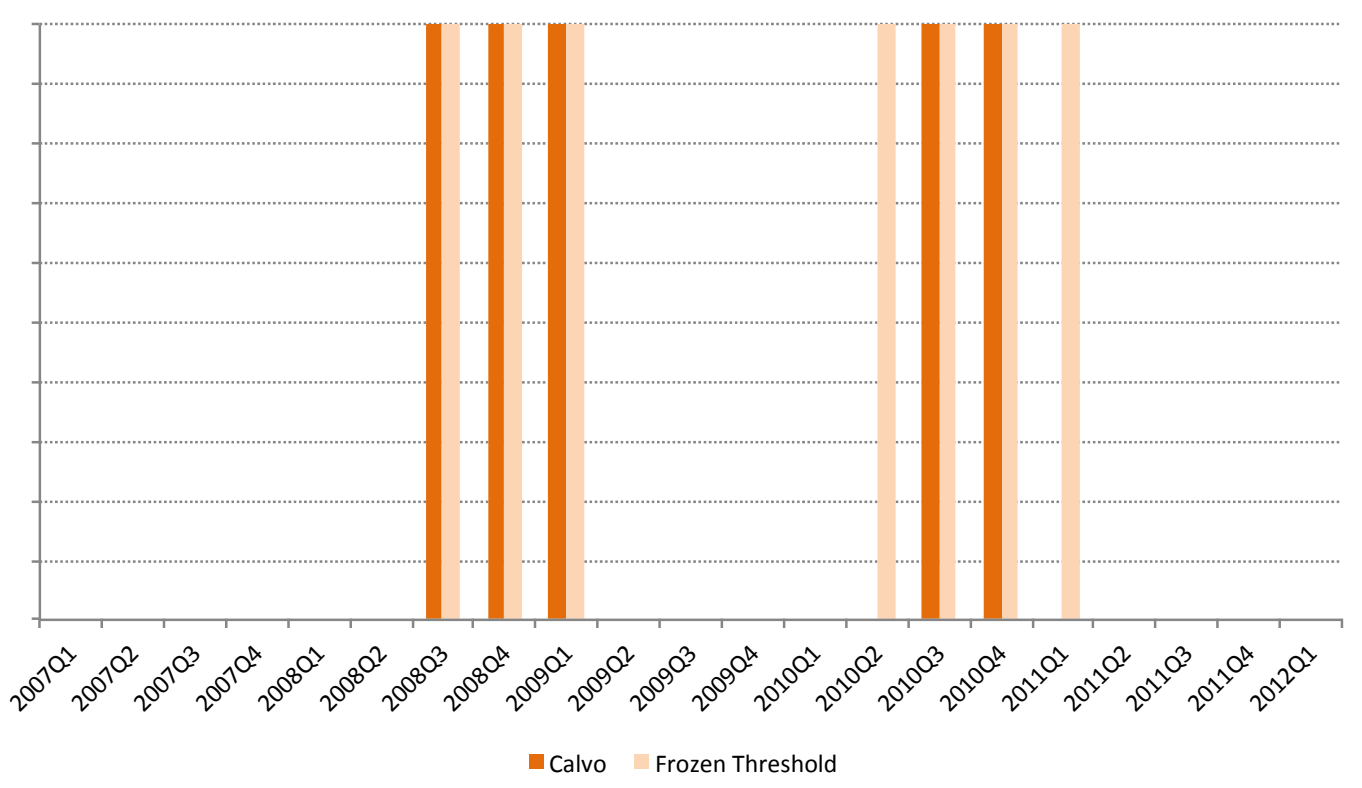

Source: Authors' estimates 